J. Perinat. Med. 15 (1987) 185

\section{Neonatal manifestations of maternal phencyclidine exposure}

\author{
Nancy L.Golden, Betty R. Kuhnert, Robert J. Sokol, Susan Martier, and Thomas \\ Williams
}

Department of Pediatrics and Reproductive Biology, Cleveland Metropolitan General Hospital/Case Western Reserve University School of Medicine, Cleveland, Ohio, U.S.A.

\section{Introduction}

Phencyclidine (angel dust) is a drug frequently abused by adolescents and young adults. For example, a New York State study of secondary school students indicated that $15.5 \%$ of students $(276,000)$ had used phencyclidine [9]. Although originally developed as a short acting anesthetic, phencyclidine's sedative and hallucinogenic effects have made it a popular drug of abuse among young people of childbearing age [11]. The use of phencyclidine by pregnant women is of concern since phencyclidine has been shown to cross the placenta and to reach the fetus [13].

There have been several reports in which phencyclidine exposure during gestation has been associated with adverse effects on the fetus. In one report, two neonates exposed in utero demonstrated a classic withdrawal syndrome [13]. They were irritable, hypertonic, jittery, and had diarrhea and vomiting for several days postpartum. A second report described neurologic and anatomic abnormalities in one infant whose mother had used large amounts of phencyclidine throughout pregnancy [2]. This infant had an abnormal neurologic examination and abnormal behavior in the neonatal period; he was jittery, irritable, hypertonic, unable to track

\section{Curriculum vitae}

NanCy L. Golden, M. D., was born in 1944 in Bridgeport, Connecticut, U.S. A. She received her M.D. from The Tufts University College of Medicine, Boston, in 1971 and qualified as a pediatrician at the University of North Carolina School of Medicine in 1976. Since 1984, she has worked at the Cape Cod Hospital Hyannis, Massachusetts. Her main fields of interest are fetal alcohol syndrome and drug effects on the fetus.

visually, and a poor feeder. Furthermore, his appearance was unusual; he had a triangularly shaped face, eyes with an antimongoloid slant, and a pointed chin. At the age of five he had spastic quadriparesis and was severely mentally retarded.

Given the reported frequency of phencyclidine use, the fact that phencyclidine crosses the placenta, and the possibility that intrauterine exposure to phencyclidine may be harmful to the fetus, we undertook a large prospective study to describe the extent of phencyclidine use during pregnancy and the characteristics of the user population [4]. The results of consecutive screening of more than 2,000 pregnant women between 1981 and 1982 showed that 7.3 percent 
gave a verbal history of phencyclidine use but only 0.8 percent could be confirmed as current users by maternal urine screening [4]. The purpose of the present study was to describe the physical characteristics, neurologic findings, behavior, and neonatal clinical course of the infants of these women, and to compare them with a group of matched control infants.

\section{Methods}

All women attending the prenatal clinics affiliated with Cleveland Metropolitan General Hospital from June, 1981 through October, 1982 were questioned on their initial visit about their drug, tobacco, and alcohol use. Trained screeners took substance abuse histories [4] and administered Michigan Alcoholism Screening Tests [10].

Study patients were defined as those who gave a verbal history of phencyclidine use during pregnancy and/or positive urine tests. Potential control patients were defined as those who did not have a history of phencyclidine use during pregnancy and whose urine tests were negative for phencyclidine. For this study, control patients were matched to study patients on maternal date of recruitment, age, ethnicity, weight, parity, weeks gestation at registration, and tobacco smoking behavior.

All patients' urines were initially screened for phencyclidine using the Enzyme Mediated Immunoassay Technique (EMIT) [1]. Specimens were initially defined as "positive" if the EMIT reading was ten units above the negative calibrator. The presence of phencyclidine was subsequently verified by gas chromatography mass spectrometry, using previously reported methodology [7]. Urines from study patients and any controls thought to be at risk for drug abuse were retested at each visit. Most of the patients had their urines tested 4-5 times prior to delivery. Furthermore, study patients and neonates had urine and blood analyses during the intrapartum and postpartum period. All bloods were negative. The results of the pharmacological analyses have been reported separ- ately [8]. Control patients' urines were also retested during the intrapartum period.

Table I. Neonatal outcome variables.

Anatomy
Widely patent sutures
Slanted eye shape
Narrow mandibular angle
Decreased joint mobility
Flexed joints

Neurologic function

Abnormal movement

Hypertonia

Hypotonia

Tremors

Decreased vision

Decreased hearing

Asymmetrical facial movement

Abnormal extra ocular movements

Decreased pupil reactivity

Miotic pupil position

Nystagmus-vertical

Nystagmus-horizontal

Increased ankle reflex

Increased knee reflex

Increased brachial reflex

Depressed suck reflex

Depressed root reflex

Depressed grasp reflex

Abnormal galant reflex

Abnormal moro reflex

Abnormal step reflex

Behavior

Poor tracking

Decreased attention

Mood (irritability)

Poor feeding

High pitched cry

Physiologic function

Heart rate $-<90>160$

Respiratory rate $-<20>60$

Sepsis

Jaundice

Hypoglycemia

Hypocalcemia

Anemia

Respiratory distress

Other

$$
\begin{aligned}
& \text { Growth } \\
& \text { Height }-<10 \%>90 \% \\
& \text { Weight }-<10 \%>90 \% \\
& \text { Head circumference - } \\
& <10 \%>90 \%
\end{aligned}
$$


Study and control neonates were evaluated mid feeding between 24 and 72 hours of age by a single examiner blind to the maternal history. This examiner is a certified pediatric nurse practitioner who is also a certified Brazelton examiner with additional experience screening Fetal Alcohol Syndrome infants [3]. Growth parameters, physical characteristics, neurologic findings, and behavior were documented according to a format based on previous descriptions of phencyclidine exposed infants (table I) $[2,13]$.

The data were analyzed in the following ways: First, descriptive statistics and paired t tests were used to compare study and control populations in regard to maternal age, race, parity, smoking behavior, and number of drugs used. Next, a hierarchial analysis was used to examine the relationship between drug use and neonatal outcome. First, paired $t$ tests were used to compare the total number of abnormal findings between the study and control infants and the frequency of abnormalities were plotted on histograms. Next, stepwise multiple regression techniques with nonforced variables were used to determine relationships between neonatal outcome and the seven classes of maternally abused substances (phencyclidine, narcotics, barbiturates, cocaine, marijuana, glue, and alcohol). Then, chi square tests were used to determine which of the dichotomous outcome variables were significantly different in study and control neonates. Finally, stepwise discriminant function analysis was used to relate specific outcome variable to phencyclidine use. A probability level $\mathrm{p}<0.05$ was accepted as significant.

\section{Results}

A total of 2,327 pregnant women were screened for phencyclidine use early in pregnancy. A verbal history of phencyclidine use during pregnancy was reported by $149(6.4 \%)$ and current use was reported and/or documented in 23 (1\%). Data collection was completed for 94 study patients, 14 of whom were verified users, and 94 matched controls. Table II summarizes
Table II. Entry of patients into neonatal PCP study.

\begin{tabular}{lc}
\hline Parameter & Number \\
\hline Women screened & 2347 \\
Positive responders & 172 \\
Historical use & 149 \\
Confirmed use & 23 \\
Positive responders lost to follow-up & 78 \\
Remaining study patients & 94 \\
Historical use & 80 \\
Confirmed use & 14 \\
\hline
\end{tabular}

the entry of patients into the study. Most patients lost to follow-up were lost due to delivery at another hospital, delivery at times when examinations could not be obtained or refusal participate. The demographic characteristics of this population has been described in depth [4] and previous analysis indicated that there were no significant demographic differences between the patients studied and those lost to followup.

Table III shows that study and control groups differed significantly only in the mean number of drugs used. This was true both within the total study sample and the subset of confirmed users. Both study and control patients most frequently abused marijuana, cocaine, barbituates, alcohol and glue in that order. Matching criteria were effective as both groups were found to be similar in maternal age, race, parity, and smoking behavior. Furthermore, other maternal characteristics, for which patients were not matched, were also similar in the study and control groups. Maternal education and socioeconomic status were not statistically different between study and control groups. Patients were also similar in terms of medical obstetric risk. Antenatal risk scores (Hobel) [12] were similar after adjustment for substance abuse. Furthermore, the infants were all at term and similar in regards to intrapartum risk and apgar scores.

A significantly increased number of abnormal findings in neonates was associated with maternal phencyclidine exposure (table IV). There 
Table III. Comparison of study and control mothers.

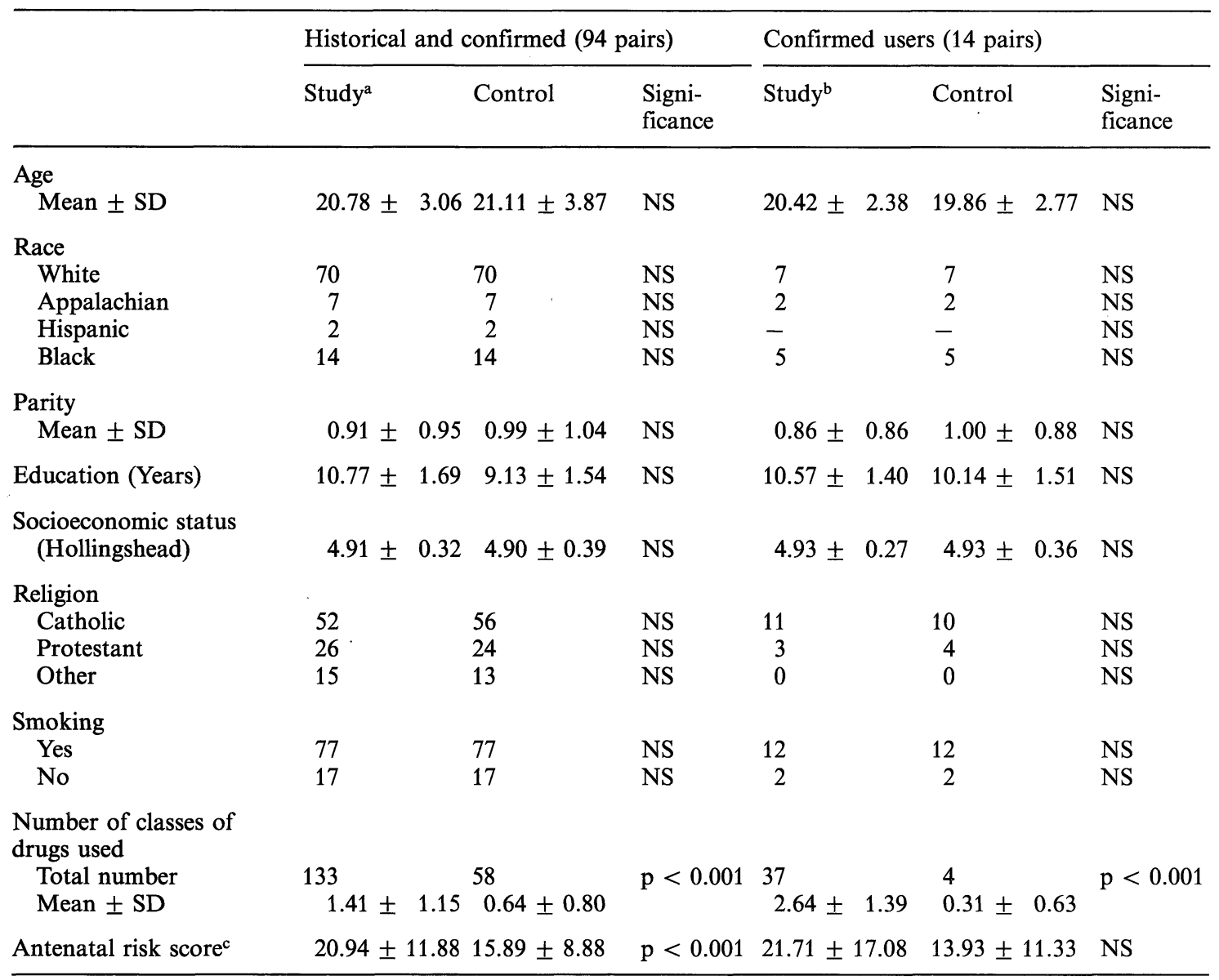

a 80 with history of use and 14 verified present users

b 14 verified users

c Modified Hobel

Table IV. Abnormal findings in neonates of phencyclidine exposed women.

\begin{tabular}{|c|c|c|}
\hline & $\begin{array}{l}\text { Study } \\
(\mathrm{N}=94)\end{array}$ & $\begin{array}{l}\text { Control } \\
(\mathrm{N}=94)\end{array}$ \\
\hline $\begin{array}{l}\text { Total number of } \\
\text { abnormal findings }\end{array}$ & 477 & 392 \\
\hline Mean $\pm S D$ & $5.07 \pm 2.93$ & $4.17 \pm 2.65$ \\
\hline Significance* & \multicolumn{2}{|c|}{$\mathrm{p}<0.01$} \\
\hline
\end{tabular}

* Paired t test

were significantly more abnormalities in both the sample which included all users, and in the subset of confirmed users. In the latter group, the study infants averaged $5.8 \pm 3.3$ abnormalities and the control group averaged $3.5 \pm 2.4$ abnormalities $(\mathrm{p}<0.02)$. While the means were different, the histograms (figure 1) of study and control patients, show that the distributions of abnormalities were similar in each group.

Many of the study patients were multiple drug users. However, stepwise multiple regression techniques showed that the number of abnormalities was related to phencyclidine use and not other drugs. Phencyclidine was the only substance of the seven classes of substances abused by the patients which accounted for a significant portion of the variance related to 


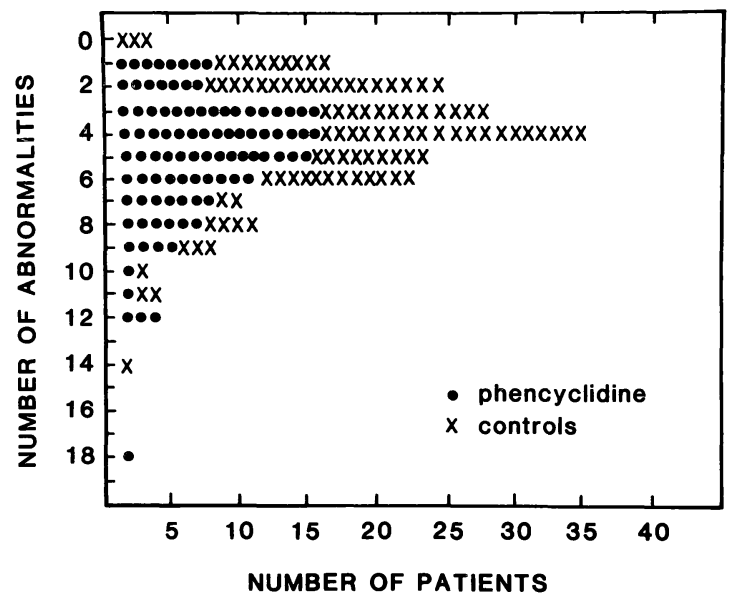

Figure 1. Number of abnormalities seen in infants of phencyclidine exposed women $(\bullet)$ and infants of controls $(x)$.

the number of abnormal findings $(F=4.38$; $\mathrm{df}=1,138 ; \mathrm{p}<0.05)$. Nevertheless, drug interactions cannot be ruled out. There were no opiate users in the study sample.

Abnormal neurological and behavioral findings were associated with maternal phencyclidine exposure (table V). Those found significantly more often in the study group included poor attention, hypertonic ankle reflexes, and depressed neonatal reflexes - grasp and rooting. The abnormal grasp reflex was the only reflex significantly related to phencyclidine use with stepwise discriminant function analysis $(\mathrm{F}=8.38 ; \mathrm{df}=1,174 ; \mathrm{p}<0.01)$. No significant relationships were found between abnormal anatomic findings and maternal phencyclidine use.

Table V. Specific abnormal findings more frequent in study infants.

\begin{tabular}{ll}
\hline Abnormal findings & $\begin{array}{l}\text { Signi- } \\
\text { ficance* } \\
(\mathrm{p}<)\end{array}$ \\
\hline Decreased attention & 0.01 \\
$\begin{array}{l}\text { Depressed neonatal reflexes } \\
\text { Grasp }\end{array}$ & 0.01 \\
$\quad$ Root & 0.03 \\
Hyperactive deep tendon reflexes ankle & 0.05 \\
\hline
\end{tabular}

* Pearson's $\chi^{2}$

\section{Discussion}

The results of this study of 188 infants suggest that infants born to women with a history of phencyclidine use during pregnancy have more abnormal neurological and behavioral findings at birth than control infants. These abnormalities are related to phencyclidine use and not to other drug use. However, interactions with other drugs cannot be ruled out. No anatomical abnormalities were detected, but the sample size may need to be much larger to see these abnormalities.

Women with a verbal history of phencyclidine use, as well as those with chemically confirmed use during pregnancy, were included in the study group for two reasons: First, phencyclidine use could be confirmed in only a small percentage of the population. This was probably due to infrequent urine testing [4]. Therefore, the frequency of phencyclidine use (which exceeds $15 \%$ in some populations [9]) would almost certainly be underestimated and many users would have been missed if only the confirmed users had been studied. The decision to include historical and confirmed users as study patients appears justified since the numbers of abnormal findings were similar in these two groups.

The results of this study do not completely agree with what has previously been reported. These findings are similar to those of a report which described an infant exposed to phencyclidine in utero with lethargy, inability to track visually, hypertonicity, and poor feeding [2]. However, the results of the present study are different in that structural abnormalities were not found. Thus, this study suggests that phencyclidine is not an anatomic teratogen but does not confirm this. A larger sample size may be needed to see anatomical abnormalities. Furthermore, the possibility exists that study infants were not exposed to phencyclidine at the time of organ formation, or that exposure was of insufficient amount or duration to cause structural defects such as those previously reported [2]. Moreover, the earlier report involved an infant also exposed simultaneously to very 
high amounts of marijuana throughout gestation.

Even though phencyclidine users are almost always multiple drug abusers [4], this study demonstrated statistically significant effects on the fetus only from phencyclidine exposure. However, previous studies have suggested a relationship between gestational exposure to barbiturates [6], marijuana [2,5], and alcohol [13] and an adverse fetal outcome. In addition, past studies have shown that narcotic exposure can have severe effects on the neonates [14]. Since none of the patients in this study were narcotics users, this study cannot address the issue of neonatal effects due to combined phencyclidine and narcotic use.
The results of this study suggest that long-term follow-up of these infants would be worthwhile. While it is unlikely that the neonatal findings would directly correlate with long-term findings, one could speculate that these children may be at increased risk of minor neurologic abnormalities and/or learning difficulties.

Our previous study indicated that phencyclidine use during pregnancy was widespread [4]. This study suggests that exposure of the fetus to phencyclidine can result in abnormal neonatal neurologic findings and behavior. Future studies must determine the long-term effects of exposing the fetus to phencyclidine.

\section{Summary}

The purpose of this study was to determine the effects of maternal phencyclidine use on the fetus. Ninety-four neonates with maternal phencyclidine exposure were compared with 94 controls. Maternal phencyclidine use was assessed by questionnaire and repeated urine testing. Mothers of study and control patients were matched for demographic characteristics. Infants were assessed between $24-72$ hours postnatally by a single examiner blind to the maternal history. The results showed that study infants had a mean of $5.02 \pm 2.93$ abnormalities

while controls had a mean of $4.13 \pm 2.65$ abnormalities $(p<0.01)$. Furthermore, study infants were more likely than controls to have poor attention, hypertonia, and depressed neonatal reflexes $(p<0.05)$. The contribution of seven drug classes to the total number of abnormalities was assessed using stepwise multiple regression. Only phencyclidine accounted for a significant proportion of the variance $(f=4.38 ; p<0.05)$. The results of this study suggest that maternal phencyclidine use may lead to abnormal neonatal neurologic findings and behavior.

Keywords: Fetus, newborn infant, pregnancy, prenatal exposure delayed effects, phencyclidine, phencyclidine abuse.

\section{Zusammenfassung}

\section{Manifestationen einer mütterlichen Phenzyklidineinnahme beim Neugeborenen}

In der vorliegenden Studie wurden die Auswirkungen einer mütterlichen Phenzyklidineinnahme auf den Feten untersucht. 94 Neugeborene von Müttern, die Phenzyklidin eingenommen hatten, wurden verglichen mit 94 Kontrollkindern. Der Phenzyklidinabusus wurde über Fragebögen und wiederholte Urintests erfaßt. Frauen aus der Phenzyklidingruppe und Frauen der Kontrollgruppe wurden nach demographischen Parametern einander zugeordnet. Die Kinder wurden von einer einzigen Person, die die mütterliche Vorgeschichte nicht kannte, innerhalb von 24-72 Stunden post partum untersucht. Kinder aus der Phenzyklidingruppe zeigten im Mittel
$5.02 \pm 2.93$ auffällige Befunde, Kinder aus der Kontrollgruppe dagegen $4.13 \pm 2.65(\mathrm{p}<0.01)$. Darüber hinaus fielen bei den Kindern der Phenzyklidingruppe im Vergleich zur Kontrollgruppe eine verminderte Reaktionsbereitschaft, ein erhöhter Tonus sowie herabgesetzte neonatale Reflexe auf $(p<0.05)$. Durch eine multiple Regressionsanalyse wurde für 7 Medikamentengruppen ermittelt, wie häufig auffällige Befunde bei den Kindern auftraten. Nur für Phenzyklidin konnte ein signifikanter Anteil an der Varianz berechnet werden ( $f=4.38$; $\mathrm{p}<0.05$ ). Die Ergebnisse zeigen, daß eine mütterliche Phenzyklidineinnahme zu auffälligen neurologischen Befunden und Verhaltensmustern beim Neugeborenen führen kann.

Schlüsselwörter: Fetus, Neugeborenes, Phenzyklidin, Phenzyklidinabusus, pränatale Exposition und Manifestation beim Kind, Schwangerschaft. 


\section{Résumé}

\section{Manifestations néo-natales de la prise maternelle de phen- cyclidine}

Le but de cette étude a été de déterminer les effets de la prise maternelle de phencyclidine sur le fœtus. On a comparé quatre vingt quatorze nouveaux-nés dont la mère avait pris de la phencyclidine avec 94 contrôles. On a déterminé la prise maternelle de phencyclidine à l'aide de questionnaires et par des analyses urinaires répétées. Les mères de l'étude et les patientes témoins ont été appariées selon les caractères démographiques. Les enfants ont été examinés entre 24 et 72 heures de vie par un seul examinateur qui ne connaissait pas l'histoire maternelle. Les résultats ont montré que les enfants de l'étude présentent en moyenne $5,02 \pm 2,93$ anomalies tandis que les contrôles ont en moyenne $4,13 \pm 2,65$ anomalies $(p<0,01)$.

En outre, les enfants étudiés présentent plus souvent que les témoins une attention faible, une hypertonie et des réflexes néonataux déprimés $(p<0,05)$. A l'aide d'une courbe de regression multiple, on a estimé le rôle de 7 types de médicaments face au nombre total d'anomalies. Seule la phencyclidine entraîne une variance significative (f $=4,38 ; \mathrm{p}<0,05$ ).

Les résultats de cette étude suggèrent que la prise maternelle de phencyclidine peut entrainer des anomalies de l'examen neurologique néonatal et des troubles du comportement.

Mots-clés: Abus de phencyclidine, effet à long terme de l'exposition prénatale, fœtus, grossesse, nouveau-né, phencyclidine.

Acknowledgements: Research supported by the National Institute on Drug Abuse - Grant number R01 DA02903 and US PHS Grant number 5M01RR-00210.

\section{References}

[1] Bastiana RJ, RC Phillips, RS Schneider, EF UllmaN: Homogeneous immunochemical drug assays. Am J Med Technol 39 (1973) 211

[2] Golden NL, RJ Sokol, IL RuBIN: Angel dust: possible effects on the fetus. Pediatrics 65 (1980) 18

[3] Golden NL, RJ Sokol, BR Kuhnert, SF BotTOMS: Maternal alcohol use and infant development. Pediatrics 70 (1982) 931

[4] Golden NL, BR KuHNERT, RJ SOKol, S MARTIER, BS BAGBY: Phencyclidine use during pregnancy. Am J Obstet Gynecol 148 (1984) 254

[5] Greenland S, KJ Staisch, N Brown, SJ Gross: The effects of marijuana use during pregnancy. I: A preliminary epidemiologic study. Am J Obstet Gynecol 143 (1982) 408

[6] Hill RM, WM Verniaud, MG Horning, LB MCCULLEY, NF MORGAN: Infants exposed in utero to anti-epileptic drugs. A prospective study. Am J Dis Child 127 (1974) 645

[7] KuHNert BR, BS BAgBy, NL Golden: Measurement of phencyclidine and two hydroxylated metabolites by selected ion monitoring. J Chromatogr 276 (1983) 433

[8] Kuhnert BR, NL Golden, CD Syracuse, BS BAGBY, PM KUHNERT: Phencyclidine disposition in mother and neonate. Res Comm Sub Abuse 5 (1984) 301
[9] MCAdams MA, RL Linder, SE LeRnER, RS BURNS (eds): Phencyclidine abuse manual. University of California, Los Angeles, Extension 13 (1980)

[10] Selzer ML: The Michigan alcoholism screening test; the quest for a new diagnostic instrument. Am J Psych 127 (1971) 89

[11] Showalter CV, WE Thornton: The increasing abuse of phencyclidine. Ill Med J 151 (1977) 387

[12] Sokol RJ, MG Rosen, J Stojkov, L ChIK: Clinical applications of high risk scoring on an obstetric service. Am J Obstet Gynecol 128 (1977) 652

[13] Strauss AA, HD Modanlou, SK Bosu: Neonatal manifestations of maternal phencyclidine (PCP) abuse. Pediatrics 68 (1981) 550

[14] Vargas GC, RS Pildes, D Vidyasagar, LG Kieth: Effect of maternal heroin addiction on 67 liveborn neonates. Clin Pediatr 14 (1975) 751

Received October 20, 1985. Revised November 18, 1985. Accepted February 10, 1986.

Betty R. Kuhnert, Ph. D.

Department of Reproductive Biology Cleveland Metropolitan General Hospital 3395 Scranton Road Cleveland, Ohio 44 109, U.S.A. 


\section{A MOderm Approcich to the

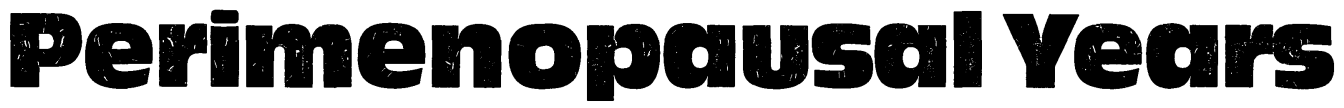

Editor: Robert B. Greenblatt

1986. $17 \times 24 \mathrm{~cm}$. VI, 256 pages. 62 illustrations. 44 tables.

Softcover DM 98,- ISBN 3110109379

(New Developments in Biosciences 2)

With advancing knowledge of the physiology of the hypothalamic-pituitaryovarian axis and how gonodal steroids influence cerebral neurohumors, bone and skin metabolism, serum lipoproteins, a new approach to the management of the perimenopausal years is now possible. The dimensions of the menopausal syndrome may now be extended to include not only vasomotor symptoms, but also metabolic disorders, bone loss, decreases in skin collagen, reversal of high and low density lipoproteins, and psychogenic disturbances (menopausal anxiety and depression, migrainoid headaches, insomnia and sexual dysfunction) that are initiated or aggravated by loss of ovarian hormones.

The text furnishes much information that is not generally known - to wit:

- estrogens and androgens diminish collagen loss of the skin,

- estrogens and progestogens not only prevent further bone decay but may increase bone density,

- cyclic progestogens added to an estrogen regimen actually lessen the natural incidence of endometrial cancer and may add some degree of protection against development of breast malignancy.

- non-bacterial urinary incontinence and nocturia may be partially or completely alleviated by estrogen therapy.

- androgens added to an estrogen regimen increase sexual fantasies and desire, and facilitate the orgasmic response.

- the danger of myocardial infarction may be reduced greatly by estrogens because of their beneficial effect on high density lipoproteins.
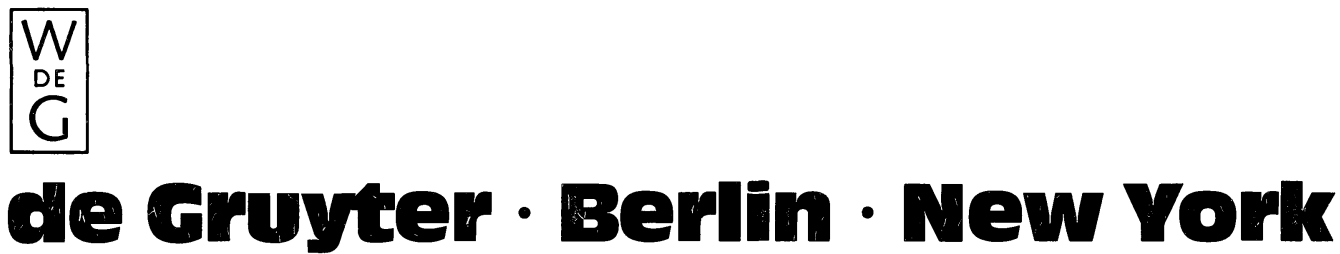